\title{
DYREKTYWY WYMIARU KARY PIENIĘŻNEJ W PRAWIE ENERGETYCZNYM
}

\section{WPROWADZENIE}

Przedmiotem regulacji ustawy z dnia 10 kwietnia 1997 r. Prawo energetyczne ${ }^{1}$ są w szczególności zasady kształtowania polityki energetycznej państwa, zasady i warunki zaopatrzenia i użytkowania paliw i energii, w tym ciepła, a także działalności przedsiębiorstw energetycznych, jak również kompetencje organów administracji publicznej właściwych w sprawach gospodarki paliwami i energią (art. 1 ust. 1 p.e.). Rozdział 7 Prawa energetycznego pt. „Kary pieniężne” poświęcony został natomiast kwestii odpowiedzialności karnoadministracyjnej z tytułu naruszeń nakazu bądź zakazu wynikającego z przepisów Prawa energetycznego lub wydanych na jego podstawie aktów administracyjnych. Odpowiedzialność karnoadministracyjna ma charakter odpowiedzialności obiektywnej, niezależnej od winy podmiotu dopuszczającego się deliktu administracyjnego, gdzie już faktyczne stwierdzenie naruszenia normy prawa administracyjnego skutkuje podleganiem odpowiedzialności karnoadministracyjnej. Dla możliwości zastosowania sankcji pieniężnej istotne jest w konsekwencji wyłącznie stwierdzenie przez właściwy organ administracji publicznej, w przypadku Prawa energetycznego - Prezesa Urzędu Regulacji Energetyki [dalej: Prezes URE], obiektywnego faktu naruszenia określonej normy przez stronę ${ }^{2}$. Przedmiotem dalszej części rozważań stanie się w związku z tym analiza dyrektyw wymiaru kary pieniężnej, które - w myśl postanowień art. 56 ust. 6 p.e. - zobowiązany jest wziąć pod uwagę Prezes URE nakładając

Dr Mariusz CzyżaK - adiunkt, Wydział Administracji, Wyższa Szkoła Kadr Menedżerskich w Koninie, ul. Zagórowska 3a, 62-500 Konin; e-mail: m.czyzak.wskm@uke.gov.pl; https://orcid. org/0000-0003-0869-3713

${ }^{1}$ Dz.U. z 2019 r., poz. 755 z późn. zm. [dalej cyt.: p.e.; Prawo energetyczne].

${ }^{2}$ Wyrok Sądu Ochrony Konkurencji i Konsumentów z dnia 23 listopada 2018 r., sygn. akt XVII AmE 106/16, Legalis nr 1887448. 
tę sankcję administracyjną. Należą do nich: stopień szkodliwości czynu, stopień zawinienia, dotychczasowe zachowanie podmiotu oraz jego możliwości finansowe.

\section{WYSOKOŚĆ KARY PIENIEŻ̇̇EJ}

Przedstawienie istoty poszczególnych kategorii przywołanych powyżej dyrektyw wymiaru kary pieniężnej poprzedzić powinno kilka słów o sposobach określenia przez ustawodawcę jej wysokości. Na gruncie obowiązującego porządku prawnego administracyjne kary pieniężne przybierać mogą bowiem postać sankcji bezwzględnie oznaczonych, gdy ustawodawca w sposób konkretny wyznacza wymiar kary pieniężnej za określone naruszenie przepisów prawa administracyjnego, oraz względnie oznaczonych, gdy oznacza zwykle jedynie granice wymiaru sankcji dolną i górną lub jedynie górną, a zdecydowanie najrzadziej wyłącznie dolną granicę wysokości kary pieniężnej ${ }^{3}$. Granice te mogą być w szczególności określane bądź to kwotowo ${ }^{4}$ bądź też pozostawać w relacji procentowej z poziomem przychodu lub określonej części przychodu podmiotu podlegającego odpowiedzialności karnoadministracyjnej ${ }^{5}$.

W przypadku kary pieniężnej grożącej za naruszenia przepisów Prawa energetycznego, ustawodawca skorzystał w zasadzie ze wszystkich tych możliwości. I tak, w niektórych przypadkach wysokość kary pieniężnej nie może być niższa niż 1\% i wyższa niż 15\% przychodu ukaranego przedsiębiorcy, osiągniętego w poprzednim roku podatkowym, a jeżeli kara pieniężna związana jest z działalnością prowadzoną na podstawie koncesji, wysokość kary nie może przekroczyć 15\%

\footnotetext{
${ }^{3}$ E. KRUK, Sankcja administracyjna, Lublin: Wydawnictwo UMCS 2013, s. 176-177.

${ }^{4}$ Np. zgodnie z postanowieniami art. 33a ustawy z dnia 12 grudnia 2003 r. o ogólnym bezpieczeństwie produktów (Dz. U. z 2016 r., poz. 2047 z późn. zm.), Prezes Urzędu Ochrony Konkurencji i Konsumentów, pełniący rolę organu nadzoru, może nałożyć na producenta lub dystrybutora produktu karę w wysokości do $100000 \mathrm{zł}$.

${ }^{5}$ Np. zgodnie z postanowieniami art. 201 ust. 1 ustawy z dnia 16 lipca 2004 r. Prawo telekomunikacyjne (Dz. U. z 2019 r., poz. 2460 z późn. zm. [dalej cyt.: p.t.]), Prezes Urzędu Komunikacji Elektronicznej nakłada karę pieniężną za naruszenia wskazane w art. 209 ust. 1 i $1^{1}$ p.t. w wysokości do 3\% przychodu ukaranego podmiotu, osiągniętego w poprzednim roku kalendarzowym, zaś zgodnie z postanowieniami art. 126 ust. 4 ustawy z dnia 23 listopada 2012 r. Prawo pocztowe (Dz. U. z 2018 r., poz. 2188 z późn. zm. [dalej cyt.: p.p.]), wysokość kary pieniężnej nakładanej przez ten organ na podstawie art. 126 ust. 1 i 2 p.p. nie może przekroczyć $2 \%$ przychodów ogółem osiągniętych przez operatora pocztowego $\mathrm{z}$ działalności pocztowej w roku obrotowym poprzedzającym wymierzenie kary, bądź osiągniętych z działalności gospodarczej w roku obrotowym poprzedzającym wymierzenie kary w przypadku podmiotu wykonującego działalność pocztową bez wymaganego wpisu do rejestru oraz podmiotu, który w roku obrotowym poprzedzającym wymierzenie kary nie wykonywał działalności pocztowej.
} 
przychodu ukaranego przedsiębiorcy, wynikającego z działalności koncesjonowanej, osiągniętego w poprzednim roku podatkowym (art. 56 ust. $2 \mathrm{f}$ p.e.). Innym razem jej dopuszczalny wymiar przybiera postać przedziałów kwotowych, w zależności od kategorii naruszenia: od $10000 \mathrm{zł}$ do $1000000 \mathrm{zł}$ (art. 56 ust. 2g p.e.), a w mniejszej wysokości - od 500 zł do 5000 zł, 10000 zł, 10000 zł do $50000 \mathrm{zl}$, od $15000 \mathrm{zl}$ do $50000 \mathrm{zł} \mathrm{lub} \mathrm{od} 50000$ zł do 250000 zł (art. 56 ust. 2 h p.e.). W razie zaniechania przekazywania Prezesowi URE informacji o rodzajach i lokalizacji infrastruktury paliw ciekłych wykorzystywanej do prowadzonej działalności, przedsiębiorstwo energetyczne wykonujące działalność polegającą na wytwarzaniu paliw ciekłych, magazynowaniu lub przeładunku paliw ciekłych, przesyłaniu lub dystrybucji paliw ciekłych, obrocie paliwami ciekłymi, w tym obrocie nimi z zagranicą, a także podmiot przywożący, podlegają karze 10000 zł oddzielnie dla każdego rodzaju i lokalizacji infrastruktury paliw ciekłych (art. 56 ust. $2 \mathrm{~h}$ pkt 8 p.e.). W jednym przypadku wysokość kary pieniężnej określona została nawet jedynie przez wskazanie dolnej granicy sankcji. Zgodnie z art. 56 ust. 2e p.e. wysokość kary pieniężnej wymierzonej w przypadku deliktu administracyjnego, o którym mowa w art. 56 ust. 1 pkt 18 p.e., polegającego na niewydaniu przez przedsiębiorstwo energetyczne zajmujące się przesyłaniem lub dystrybucją energii elektrycznej, warunków przyłączenia w wymaganym ustawą terminie (art. 7 ust. $8 \mathrm{~g}$ p.e.), nie może być niższa niż 3000 zł za każdy dzień zwłoki w wydaniu warunków przyłączenia.

W sytuacji, gdy organowi władzy publicznej umocowanemu ustawowo do nakładania kary administracyjnej o charakterze finansowym (np. Prezesowi URE), pozostawiono pewną swobodę decyzyjną, określając jedynie dolną lub górną granicę bądź przedział wysokości tej sankcji, ustawodawca przydaje mu zwykle do pomocy przesłanki normatywne, którymi kierować powinien się określając wymiar kary pieniężnej za konkretne naruszenie stanowiące delikt administracyjny. Wobec faktu, iż odpowiedzialność karnoadministracyjna, jak już wspomniano powyżej, ma zwykle charakter obiektywny, zastosowanie tych dyrektyw służy zatem indywidualizacji tejże odpowiedzialności. Organ uprawniony do nałożenia sankcji zobowiązany jest ustalić stan faktyczny towarzyszący naruszeniu z uwzględnieniem okoliczności pozwalających na ocenę wagi deliktu administracyjnego, w szczególności, w jakim stopniu naruszenie obowiązku administracyjnoprawnego nastąpiło w następstwie okoliczności, na które podmiot podlegający karze pieniężnej miał wpływ, a także w jakiej proporcji pozostaje ono względem wagi dóbr chronionych sankcją administracyjną ${ }^{6}$.

${ }^{6}$ R. Stankiewicz, Komentarz do art. 189d, [w:] Kodeks postępowania administracyjnego. Komentarz, red. R. Hauser, M. Wierzbowski, Legalis 2018/el., teza 1. 


\section{STOPIEŃ SZKODLIWOŚCI}

W pierwszym rzędzie Prezes URE zobowiązany jest zatem uwzględnić przy wymiarze kary pieniężnej kryterium stopnia szkodliwości czynu. Prawu karnemu znane jest pojęcie stopnia szkodliwości społecznej. W opinii judykatury na gruncie ustawy karnej „Stopień społecznej szkodliwości czynu jest tą immanentną cechą czynu, która pozwala na odróżnienie czynów błahych od poważnych i uznanie za przestępstwo tylko takich, które faktycznie i realnie szkodzą określonym dobrom jednostki, bądź dobru społecznemu. Ta zmienna cecha czynu, który formalnie wyczerpuje wszystkie znamiona danego typu czynu zabronionego, podlega indywidualnemu stopniowaniu i w zależności od konkretnych okoliczności podmiotowych, jak i przedmiotowych może być bądź to znikoma, bądź nieznaczna, bądź w końcu wysoka lub nawet szczególnie wysoka" " . Jakkolwiek zatem ustawodawca posłużył się w Prawie energetycznym sformułowaniem „stopień szkodliwości czynu”, to oczywiste jest, że mowa tutaj o szkodliwości rozumianej z perspektywy określonych dóbr istotnych społecznie, w które dany delikt administracyjny godzi.

Dodać należy, że tenże ustawodawca wskazał w ustawie z dnia 6 czerwca 1997 r. - Kodeks karny ${ }^{8}$ trzy stopnie szkodliwości społecznej - znikomy, nieznaczny i znaczny. Zgodnie z wytycznymi wynikającymi z postanowień art. $115 \S 2$ k.k. przy ocenie stopnia społecznej szkodliwości czynu sąd wymierzający karę kryminalną zobowiązany jest uwzględnić: rodzaj i charakter naruszonego czynem dobra, rozmiary wyrządzonej bądź grożącej szkody, sposób i okoliczności popełnienia czynu, wagę naruszonych przez sprawcę czynu obowiązków, a także postać zamiaru, motywację sprawcy, jak również rodzaj naruszonych przezeń reguł ostrożności i stopień ich naruszenia. W świetle dyspozycji wspomnianego przepisu przyjęto zatem w ustawodawstwie karnym przedmiotowo-podmiotową koncepcję oceny społecznej szkodliwości czynu, ponieważ wymaga od organu stosującego prawo karne uwzględnienia zarówno okoliczności należących do strony przedmiotowej czynu zabronionego, a mianowicie - rodzaju i charakteru naruszonego dobra, rozmiarów wyrządzonej bądź grożącej szkody, sposobu i okoliczności popełnienia czynu, wagi naruszonych czynem obowiązków, rodzaju naruszonych reguł ostrożności i stopnia ich naruszenia, jak również takich, które określane są jako strona podmiotowa czynu zabronionego - postaci zamiaru i motywacji sprawcy czynu'

${ }^{7}$ Wyrok Sądu Apelacyjnego w Katowicach z dnia 13 stycznia 2005 r., sygn. akt II AKa 455/04, Legalis $\mathrm{nr} 71610$.

${ }^{8}$ Dz. U. z 2019 r., poz. 1950 z późn. zm. [dalej cyt.: k.k.].

${ }^{9}$ P. Daniluk, Komentarz do art. 115, [w:] Kodeks karny. Komentarz, red. R. Stefański, Legalis 2019/el., teza B.21. 
Wydaje się, że nic nie stoi na przeszkodzie, aby poddając ocenie stopień szkodliwości społecznej deliktu administracyjnego na gruncie Prawa energetycznego, posiłkować się elementami znanymi ustawodawstwu karnemu i nauce prawa karnego ${ }^{10}$. Odwołać należy się jednakże w tym przypadku wyłącznie do aspektu przedmiotowego szkodliwości społecznej, bowiem sama postać zamiaru i motywacja, stanowiące wymiar podmiotowy szkodliwości społecznej, związane są z kryterium stopnia zawinienia, a ten wyodrębniony został jako osobna przesłanka wymiaru kary w art. 56 ust. 6 p.e.

Wspomnieć wypada, że w orzecznictwie napotkać można stanowisko wiążące z materią szkodliwości społecznej poszczególnych typów deliktów administracyjnych takie elementy, jak kwestia zawinienia, czy też zakres naruszenia. Ten pierwszy dotyczy naruszenia polegającego na stosowaniu stawek opłat wyższych od zatwierdzonych w taryfie określonej w decyzji Prezesa URE, o którym mowa w art. 56 ust. 1 pkt 6 p.e. W opinii Sądu Ochrony Konkurencji i Konsumentów każde „świadome, a więc umyślne naruszenie taryfy przez przedsiębiorcę energetycznego nie może być ocenione inaczej, niż jako czyn o niebagatelnej szkodliwości”, ponieważ stanowi niedopuszczalną ingerencję w takie dobro szczególnie chronione, jakim jest transparentność zasad ustalania opłat taryfowych i ich ustalanie ściśle według obowiązującego prawa ${ }^{11}$. Skala naruszenia jest uznawana za znaczną m.in. wówczas, gdy „niezgodność składu wprowadzonej do obrotu benzyny bezołowiowej z normami jakościowymi w zakresie trzech parametrów, a w przypadku oleju napędowego w zakresie dwóch parametrów, stwierdzona w kilku badaniach kontrolnych, stwarzając tym samym zagrożenie dla funkcjonowania pojazdów silnikowych oraz środowiska naturalnego" $" 12$.

Poświęcić również trzeba nieco miejsca instytucji odstąpienia od nałożenia kary pieniężnej w Prawie energetycznym. Otóż w myśl postanowień art. 56 ust. 6a p.e., Prezes URE może odstąpić od wymierzenia kary pieniężnej, jeśli stopień szkodliwości czynu jest znikomy, zaś podmiot jej podlegający zaprzestał naruszania prawa bądź też zrealizował spoczywający na nim obowiązek. Kiedy uznać można zatem, że stopień szkodliwości deliktu administracyjnego jest znikomy? Na gruncie ustawy karnej, stopień znikomy wyłącza możliwość uznania określonego czynu za przestępstwo (art. $1 \S 2$ k.k.). Orzecznictwo dotyczące sfery prawa

${ }^{10}$ Zob. np. wyroki SOKiK: z dnia 23 października 2019 r., sygn. akt XVII AmE 360/18, Legalis nr 2257355; z dnia 13 sierpnia 2019 r, sygn. akt XVII AmE 236/17, Legalis nr 2257705; z dnia 27 listopada 2018 r., sygn. akt XVII AmE 297/18, Legalis nr 2127543.

${ }^{11}$ Wyrok Sądu Ochrony Konkurencji i Konsumentów z dnia 12 maja 2017 r., sygn. akt XVII AmE 118/15, Legalis nr 1751936.

${ }^{12}$ Wyrok Sądu Okręgowego w Warszawie z dnia 30 czerwca 2015 r., sygn. akt XVII AmE 49/14, Legalis nr 1325972. 
karnego wskazuje, że ocena stopnia szkodliwości społecznej konkretnego czynu powinna mieć charakter oceny całościowej, uwzględniającej okoliczności wskazanie w przywołanym już powyżej przepisie art. $115 \S 2$ k.k., a nie sumą bądź też pochodną poszczególnych ocen cząstkowych wynikających z poszczególnych okoliczności ${ }^{13}$. Dlatego też również znikomość szkodliwości deliktu administracyjnego wynikać musi z kompleksowej oceny jego „pejoratywnego wymiaru” wskazującej w szczególności na: nikłą wartość naruszonego dobra; brak lub niewielkie rozmiary zaistniałej bądź grożącej szkody albo jej niezwłoczne naprawienie; sposób i okoliczności popełnienia deliktu administracyjnego wskazujące na próbę zapobieżenia powstaniu naruszenia lub działaniu w szczególnej sytuacji osobistej; błahą wagę lub niewielkie opóźnienie w realizacji naruszonych obowiązków czy też brak niekorzystnych skutków po stronie podmiotu, względem którego dany obowiązek miał być spełniony; postać zamiaru wskazującą na brak świadomości realizacji znamion deliktu administracyjnego; motywację sprawcy wyłączającą intencjonalne dopuszczenie się deliktu administracyjnego lub działanie z godziwych pobudek; naruszenie reguł ostrożności pomimo zachowania należytej ostrożności i staranności działania bądź naruszenie ich w znikomym stopniu.

\section{STOPIEŃ ZAWINIENIA}

Niezależnie od obiektywnego charakteru odpowiedzialności karnoadministracyjnej identyfikowanego, jak wskazano powyżej, głównie z wyeliminowaniem kwestii zawinienia z kręgu przesłanek odpowiedzialności prawnej, nie można jednak zapominać, że zgodnie z postanowieniami, przywołanego już powyżej art. 56 ust. 6 p.e., ustalając wysokość kary pieniężnej, Prezes URE zobowiązany jest uwzględnić wśród czterech ustawowych dyrektyw wymiaru tejże sankcji również stopień zawinienia. Kwestia winy nie pozostaje zatem na gruncie ustawy Prawo energetyczne na uboczu zainteresowania ustawodawcy, ale poddana musi zostać analizie przez organ nakładający karę pieniężną, mając na uwadze, jak podnosi doktryna, „konieczność indywidualizacji odpowiedzialności administracyjnej, czyli uwzględnienia przy orzekaniu okoliczności związanych z danym podmiotem i jego konkretną sytuacją stanowiącą podstawę wymienienia administracyjnej kary pieniężnej"14.

${ }^{13}$ Wyrok Sądu Najwyższego z dnia 10 lutego 2009 r., sygn. akt WA 1/09, Legalis nr 238904; wyrok Sądu Apelacyjnego w Lodzi z dnia 18 marca 2014 r., sygn. akt II AKa 28/14, Legalis nr 831415.

${ }^{14}$ K.A. Tarniowy, Komentarz do art. 56, [w:] Prawo energetyczne. Komentarz, red. M. Kuliński, Legalis 2017/el., teza IV.7. 
Inaczej spojrzeć należy jednakże na materię stopnia zawinienia osoby fizycznej podlegającej karze pieniężnej, inaczej natomiast na stopień zawinienia, który przypisać można podmiotowi o charakterze korporacyjnym, zwłaszcza, że w doktrynie niekiedy neguje się zdolność osoby prawnej do ponoszenia winy z uwagi na fakt, iż jej istotą jest osobista zarzucalność uwarunkowana zdolnością sprawcy do powstania w jego psychice motywacji skłaniającej do przestrzegania określonego rodzaju norm ${ }^{15}$.

W przypadku winy osób prawnych i jednostek organizacyjnych osobowości prawnej nieposiadających, a podlegających odpowiedzialności karnoadministracyjnej, pomocna okazać mogłaby się przy ocenie stopnia zawinienia rzutującego na wymiar kary pieniężnej, koncepcja winy podmiotu zbiorowego przyjęta przez ustawodawcę w ustawie z dnia 28 października 2002 r. o odpowiedzialności podmiotów zbiorowych za czyny zabronione pod groźbą kary ${ }^{16}$, gdzie - na wzór regulacji cywilnoprawnych - przyjęto w art. 5 pkt 1 u.o.p.z. dwie przesłanki odpowiedzialności podmiotu zbiorowego: $\mathrm{z}$ tytułu winy w wyborze bądź winy w nadzorze tzn. albo braku należytej staranności w wyborze osoby fizycznej, za której czyn podmiot zbiorowy odpowiada, albo braku właściwego nadzoru ze strony podmiotu zbiorowego nad tą osobą ${ }^{17}$.

Pamiętać należy również, że zgodnie z postanowieniami art. 416 ustawy z dnia 23 kwietnia 1964 r. Kodeks cywilny ${ }^{18}$, w przypadku czynu niedozwolonego, osoba prawna zobowiązana jest naprawić szkodę wyrządzoną z winy jej organu, pod pojęciem którego rozumieć należy piastuna organu osoby prawnej lub inne osoby, które umocowane zostały do występowania w imieniu osoby prawnej. Wina organu utożsamiana jest natomiast $\mathrm{z}$ możliwością przypisania winy osobie fizycznej występującej w charakterze organu osoby prawnej. Rygorystyczne podejście do problemu ustalenia winy wymagałoby zatem $\mathrm{m}$.in. indywidualizacji piastuna organu, a zatem wskazania konkretnej osoby fizycznej, której bezprawne zachowanie doprowadziło do powstania szkody. Z uwagi na to, że to na poszkodowanym spoczywa obowiązek wykazania zaistnienia przesłanki winy, w konsekwencji również poszkodowanego obciąża obowiązek wskazania osoby fizycznej, której zachowanie szkodę spowodowało, a temu mogą towarzyszyć istotne trudności dowodowe. Dlatego też ze względów praktycznych, tak doktryna, jak i judykatura akceptują możliwość ustalenia winy organu osoby prawnej opierając się m.in. na

${ }^{15}$ Zob. M. KRÓL-BogomiLSKA, Kary pieniężne w prawie antymonopolowym, Warszawa: Wydawnictwo KiK 2001, s. 97-99.

${ }^{16}$ Dz. U. z 2019 r., poz. 628 z późn. zm. [dalej cyt.: u.o.p.z.].

${ }^{17}$ Zob. postanowienie Sądu Najwyższego z dnia 5 maja 2009 r., sygn. akt IV KK 427/08, Legalis $\mathrm{nr} 158190$.

${ }^{18}$ Dz. U. z 2019 r., poz. 1145 z późn. zm. [dalej cyt.: k.c.]. 
koncepcji tzw. winy organizacyjnej lub winy anonimowej. Istotą tej pierwszej jest postrzeganie źródła winy organu osoby prawnej w niewłaściwej organizacji jej struktury i zasad funkcjonowania, które doprowadziły do zaistnienia zdarzenia prowadzącego do powstania szkody. Wina anonimowa, wykorzystywana także na gruncie odpowiedzialności za czyn cudzy, o którym mowa w art. 430 k.c., zakłada natomiast, iż czynu wyrządzającego szkodę dokonała niezidentyfikowana osoba fizyczna działająca $\mathrm{w}$ ramach struktury organizacyjnej podmiotu podlegającego odpowiedzialności ex delicto ${ }^{19}$.

Posiłkując się konstrukcją cywilnoprawnej winy organizacyjnej i anonimowej można zatem pokusić się o stwierdzenie, że sam podmiot zbiorowy z natury rzeczy nie dokonuje fizycznie deliktu administracyjnego, ale czynności prowadzących do wypełnienia jego znamion dopuszczają się osoby fizyczne działające $\mathrm{w}$ imieniu tego podmiotu i w ramach jego działalności. Podejmują one określone zachowania (działania bądź zaniechania działania) w oparciu o reguły organizacji i funkcjonowania danego podmiotu zbiorowego wynikające $\mathrm{z}$ obowiązujących $\mathrm{w}$ nim regulacji wewnętrznych, posiadanych przez te osoby fizyczne upoważnień, bądź z tytułu wiążącego je z określonym podmiotem zbiorowym stosunku zobowiązaniowego. W takim przypadku ocena stopnia zawinienia deliktu administracyjnego, za który odpowiada podmiot zbiorowy, wypływać powinna zatem przede wszystkim z analizy okoliczności sprawowania nadzoru nad aktywnością osoby fizycznej, która występowała w imieniu podmiotu zbiorowego (również z uwzględnieniem tego, czy działała w sposób uprawniony czy nie) i której działanie bądź zaniechanie doprowadziło do naruszenia przepisów prawa skutkującego odpowiedzialnością karnoadministracyjną, w szczególności przepisu art. 56 ust. 1 p.e. Posiłkować tutaj należy się poglądem Sądu Ochrony Konkurencji i Konsumentów odnoszącym się do oceny stopnia zawinienia. W jego opinii na wymiar nakładanej kary pieniężnej wpływa niewątpliwe nie tylko rozróżnienie pomiędzy winą umyślną oraz winą nieumyślną - niedbalstwem (a zatem rozróżnienie to, jak się wydaje, powinno być zdaniem sądu uwzględnione - M.Cz.), ale przy ocenie tego ostatniego ,istotnym będzie, jakie zasady starannego działania zostały przez ponoszącego winę naruszone" 20 . W konsekwencji, przy określaniu wymiaru kary z uwzględnieniem stopnia zawinienia, analizie poddana musi zostać również kwestia kategorii naruszonych zasad starannego działania, których przestrzegania wymaga profesjonalne prowadzenie spraw podmiotu zbiorowego.

${ }^{19}$ M. ZeleK, Komentarz do art. 416, [w:] Kodeks cywilny. Komentarz, t. II, red. M. Gutowski, Legalis 2019/el., tezy 12-14.

${ }^{20}$ Wyrok Sądu Ochrony Konkurencji i Konsumentów z dnia 18 lipca 2013 r., sygn. akt XVII AmE 119/11, Legalis nr 1326114. 
W przypadku osoby fizycznej podlegającej karze pieniężnej stopień zawinienia utożsamiać można z postacią zamiaru sprawcy deliktu administracyjnego, a więc, czy dopuszczając się czynu stanowiącego naruszenie prawa administracyjnego działał on w zamiarze bezpośrednim, ewentualnym, czy też z naruszeniem pewnych reguł ostrożności, działając lekkomyślnie. Mając na uwadze treść art. 9 § 1 k.k., czyn uznaje się za popełniony umyślnie wówczas, gdy sprawca ma zamiar jego popełnienia, a zatem chce go popełnić bądź też przewidując możliwość jego popełnienia, godzi się na to. Przybiera on postać zamiaru bezpośredniego, który związany jest nierozerwalnie $\mathrm{z}$ chęcią popełnienia określonego czynu, której towarzyszy świadomość realizacji znamion typu czynu zabronionego, bądź też zamiaru wynikowego, gdy sprawca może przewidywać, że w miejsce albo obok stanu rzeczy objętego chęcią, zrealizuje inny, który nie jest tą chęcią objęty ${ }^{21}$. Zamiar ewentualny polega natomiast na tym, że sprawca nie chce popełnienia czynu zabronionego, ale przewidując możliwość jego popełnienia, godzi się na to, akceptując w konsekwencji mogący nastąpić stanu rzeczy. W przypadku lekkomyślności sprawca natomiast świadomie narusza pewne zasady ostrożności i przewiduje możliwość popełnienia czynu zabronionego, przypuszczając jednocześnie, że go uniknie $^{22}$. W świetle przepisu art. 9 § 2 k.k. na nieumyślność składają się z kolei trzy elementy ${ }^{23}$. Po pierwsze, sprawca czynu nieumyślnego popełnia go, jakkolwiek nie ma zamiaru jego popełnienia, ponieważ zamiar taki mając, popełniłby czyn umyślnie. Po drugie, nieumyślność związana jest z niezachowaniem przez sprawcę reguł ostrożności w danych okolicznościach wymaganych. Po trzecie, związana jest z nią kwestia przewidywania możliwości popełnienia czynu zabronionego (świadoma nieumyślność - lekkomyślność) bądź możliwość przewidywania możliwości jego popełnienia (nieświadoma nieumyślność - niedbalstwo), prowadząca kiedyś do wyodrębnienia dwóch postaci nieumyślności - lekkomyślności i niedbalstwa. Ocena naganności zachowania w przypadku winy nieumyślnej na gruncie prawa karnego wymaga zatem zbadania przestrzegania „reguł ostrożności”, zaś na gruncie prawa cywilnego wymaga ona dochowania „należytej staranności”24.

Pamiętać jednak należy, że ocena stopnia zawinienia, tak w przypadku osób fizycznych, ale przede wszystkim podmiotów zbiorowych, sprawia poważne trud-

\footnotetext{
${ }^{21}$ Postanowienie Sądu Najwyższego z dnia 13 maja 2015 r., sygn. akt II KK 60/15, Legalis nr 1285380

${ }^{22}$ Wyrok Sądu Najwyższego z dnia 15 grudnia 2017 r., sygn. akt SNO 51/17, Legalis nr 1713888.

${ }^{23}$ A. GrzeŚKowiak, Komentarz do art. 9, [w:] Kodeks karny. Komentarz, red. A. Grześkowiak, K. Wiak, Legalis 2019/el., teza IV.2.

${ }^{24}$ M. URBaŃSKA-ARENDT, Wpływ EKPC na uwzględnienie ,winy” jako przesłanki dopuszczalności nakładania kar pieniężnych $w$ orzecznictwie dotyczacym deliktów prawa antymonopolowego i energetycznego, „Internetowy Kwartalnik Antymonopolowy i Regulacyjny” 6 (2017), s. 45.
} 
ności, ponieważ niełatwo ją zwymiarować. Dlatego też wydaje się, iż jakkolwiek koniecznie należy ją uwzględnić w toku określania wysokości kary pieniężnej, to w niektórych przypadkach wymagających zastosowania narzędzi karnoadministracyjnych za naruszenia Prawa energetycznego, będzie miała ona charakter wspomagający względem takich dyrektyw jak dotychczasowe zachowanie, możliwości ekonomiczne, a nawet stopień szkodliwości.

\section{MOŻLIWOŚCI FINANSOWE}

Istotą administracyjnej kary pieniężnej, analogicznie jak chociażby kary grzywny znanej prawu karnemu, prawu wykroczeń, czy też prawu karnemu skarbowemu, jest wyrządzenie dolegliwości o charakterze ekonomicznym powodującej uszczerbek w majątku ukaranego. Nie budzi wobec tego wątpliwości, że ustawodawca wiąże w tym przypadku wymiar sankcji z możliwościami finansowymi podmiotu podlegającego odpowiedzialności karnoadministracyjnej. Brak takiej asocjacji prowadziłby bowiem do wniosku, że nie jest dla niego istotne, na ile egzekucja kary pieniężnej jest pożądana i skuteczna, co podważałoby racjonalność polityki legislacyjnej. Niezależnie zatem od wyznaczenia pewnych ustawowych granic wysokości tej kategorii sankcji, samych przez się dostosowanych do kategorii naruszeń porządku prawnego wyznaczonego przepisami Prawa energetycznego, wprowadzono obowiązek dalszego miarkowania kary pieniężnej nakładanej na podstawie art. 56 ust. 1 p.e., poprzez konieczność uwzględnienia możliwości finansowych karanego podmiotu. W literaturze przedmiotu podnosi się, że przesłanka tego rodzaju służy w pewnym stopniu złagodzeniu sposobu określania wymiaru kary pozostającego $\mathrm{w}$ relacji do przychodu podmiotu podlegającego $\mathrm{karze}^{25}$, aczkolwiek obecna ona jest również tam, gdzie granice kary pieniężnej przybierają postać przedziału kwotowego.

Przesłanki możliwości finansowych nie należy identyfikować wyłącznie z funkcją fiskalną, którą przypisać można karze pieniężnej, jak i każdej innej kategorii daniny publicznej, skoro w myśl postanowień art. 111 pkt 12 ustawy z dnia 27 sierpnia 2009 r. o finansach publicznych ${ }^{26}$, kary te zaliczane są do dochodów publicznych. Inaczej rzecz ujmując, nie wskazuje ona na wymóg maksymalizacji wymiaru kary pieniężnej do górnego poziomu możliwego do uzyskania od podmiotu podlegającego odpowiedzialności karnoadministracyjnej. Ma ona stanowić jednak obciążenie dotkliwe i proporcjonalne względem charakteru naruszenia, ale

25 S. Piątek, Prawo telekomunikacyjne. Komentarz, Warszawa: C.H. Beck 2019, s. 1481.

${ }^{26}$ Dz. U. z 2019 r., poz. 869 z późn. zm. 
nie nadmierne na tyle, aby doprowadzić do istotnego i nieuzasadnionego pogorszenia sytuacji finansowej karanego podmiotu.

Także judykatura wydaje się wiązać poziom dolegliwości kary pieniężnej nakładanej na podstawie art. 56 ust. 1 p.e. z wpływem na sytuację majątkową i finansową karanego podmiotu, skoro wskazuje, że „nie można mówić o znacznej dolegliwości kary pieniężnej” wówczas, gdy kara pieniężna jest na tyle niska $\mathrm{w}$ stosunku do jego przychodu i dochodu, że w konsekwencji w żaden sposób nie wpłynęłaby ona na jego sytuację majątkową i finansową ${ }^{27}$. Bazowanie przy określaniu wymiaru kary pieniężnej wyłącznie na przesłance możliwości ekonomicznych podmiotu jej podlegającego nie jest jednak dopuszczalne. Sąd Najwyższy stanął przy tym na stanowisku, że niewłaściwe jest w szczególności ograniczenie weryfikacji wysokości kary pieniężnej nałożonej na przedsiębiorcę do sprawdzenia, czy mieści się ona w ustawowych granicach jej wymiaru. Należy bowiem uwzględnić sytuację finansową przedsiębiorcy będącego osobą fizyczną na etapie oceny proporcjonalności wymierzonej kary, z uwzględnieniem jej funkcji rozumianych w naukach prawnych jako cel, zadanie bądź skutki działań podejmowanych przez administrację publiczną ${ }^{28}$, jak również innych przesłanek wymiaru kary wskazanych w art. 56 ust. 6 p.e. ${ }^{29}$ Do funkcji tych należy zaliczyć w pierwszej kolejności funkcje - prewencyjną i represyjną, przy czym orzecznictwo wydane na gruncie ustawy Prawo energetyczne wskazuje obok nich również funkcję „edukacyjną"30, która utożsamiać trzeba jednak z funkcją pokrewną tzw. prewencji ogólnej. Sankcja, o której mowa w art. 56 ust. 1 p.e., „ma pełnić funkcję prewencji szczególnej i ogólnej, a więc być zarówno realną, odczuwalną dolegliwością dla ukaranego podmiotu, będącą reakcją na naruszenie przepisów, ale także wyraźnym ostrzeżeniem na przyszłość, zapobiegającym powtarzaniu nagannych zachowań"31. Obydwie przywołane powyżej funkcje, tak represyjna, jak i prewencyjna, są powiązane w zasadniczy sposób z charakterem dolegliwości towarzyszącej administracyjnej karze pieniężnej, której istotą jest wymierzenie uszczerbku finansowego, a zatem represja prowadzić ma do „zubożenia” w majątku podmiotu podlegającego karze, a w ten sposób do zapobieżenia narusze-

\footnotetext{
${ }^{27}$ Wyrok Sądu Apelacyjnego w Warszawie z dnia 16 grudnia 2016 r., sygn. akt VI ACa 1365/15, Legalis $\mathrm{nr} 1576321$.

${ }^{28}$ P. PrzyBysz, Funkcje sankcji administracyjnych, [w:] Sankcje administracyjne, red. M. Stahl, R. Lewicka, M. Lewicki, Warszawa: Wolters Kluwer Polska Sp. z o.o. 2011, s. 162.

${ }^{29}$ Postanowienie Sądu Najwyższego z dnia 5 grudnia 2013 r., sygn. akt III SK 24/13, Legalis nr 753722

${ }^{30}$ Wyrok Sądu Apelacyjnego w Warszawie z dnia 8 lutego 2017 r., sygn. akt VI ACa 1922/15, Legalis nr 1636709.

${ }^{31}$ Wyrok Sądu Ochrony Konkurencji i Konsumentów z dnia 9 maja 2016 r., sygn. akt XVII AmE 130/14, Legalis nr 1751948.
} 
nia prawa w przyszłości, nakłaniając go do przestrzegania w przyszłości reguł prowadzenia działalności gospodarczej w obszarze energetyki, a wyznaczonych Prawem energetycznym.

\section{DOTYCHCZASOWE ZACHOWANIE}

Jedną z dyrektyw wymiaru kary pieniężnej wskazanych w art. 56 ust. 6 p.e. jest również dotychczasowe zachowanie podmiotu podlegającego karze pieniężnej. Samo „zachowanie” w znaczeniu potocznym to „sposób, w jaki zachowują się ludzie" ${ }^{32}$. Zachowanie odnosić należy zatem w pierwszym rzędzie do czynu polegającego tak na działaniu, jak i na zaniechaniu działania, a zatem tak, jak postrzega pojęcie zachowania ustawodawca na gruncie prawa karnego. W ścisłym tego słowa znaczeniu określenie „dotychczasowe zachowanie” stanowić mogłyby zatem jedynie przesłankę wymiaru kary możliwą do uwzględnienia przy procesie nakładania kary na osobę fizyczną będącą sprawcą deliktu administracyjnego określonego w dyspozycji art. 56 ust. 1 p.e., bądź kierownika przedsiębiorstwa energetycznego, o którym mowa w art. 56 ust. 1 p.e. Pomimo tej nieścisłości terminologicznej oczywiste jest, że ustawodawcy chodziło tutaj jednak de facto o dyrektywę, której treścią jest raczej dotychczasowa działalność podmiotu podlegającego karze, tak będącego osobą fizyczną, jak i podmiotem zbiorowym. Nadmienić należy, że kryterium „dotychczasowej działalności podmiotu” posługuje się ustawodawca np. w przepisie art. 210 ust. 2 Prawa telekomunikacyjnego i art. 126 ust. 8 Prawa pocztowego.

Zdaniem K.A. Tarniowego przesłankę przedmiotową utożsamiać trzeba ze „sposobem wykonywania obowiązków ustawowych przez adresata kary w okresie bezpośrednio poprzedzającym wszczęcie postępowania administracyjnego $\mathrm{w}$ tym przedmiocie", przy czym wskazuje, iż brak uprzedniej karalności wynikającej $\mathrm{z}$ naruszenia postanowień art. 56 p.e. stanowić powinien przesłankę łagodzącą skutkującą obniżeniem wysokości kary, a uporczywe lekceważenie obowiązków ustawowych w tym zakresie - okoliczność obciążającą ${ }^{33}$. Zgodzić należy się z kierunkiem takiego toku rozumowania, jeśli chodzi o samą kwestię oceny „zachowania” karanego podmiotu z punktu widzenia jego legalności. Nie byłoby przecież celowe uwzględnianie przy wymiarze przedmiotowej sankcji aspektów faktycznych jego dotychczasowej działalności, takich jak np. rozmiary prowadzonej działalności gospodarczej, liczba klientów, realizacja planów biznesowych, współ-

\footnotetext{
${ }^{32}$ www.sjp.pwn.pl [dostęp: 21.08.2019].

33 Tarniowy, Komentarz do art. 56, teza IV.10.
} 
praca z innymi przedsiębiorcami, itp. Odnotować w tym miejscu jednak wypada, że w literaturze przedmiotu zwraca się również uwagę na potrzebę uwzględnienia korelacji wyższego prawdopodobieństwa wystąpienia naruszenia przepisów Prawa energetycznego skutkującego odpowiedzialnością karnoadministracyjną z większymi rozmiarami prowadzonej działalności i to, jak się wydaje, jako okoliczność łagodzącą ${ }^{34}$. Zadać należy przy tym jednak pytanie, czy to właśnie od podmiotu o znacznych rozmiarach prowadzonej działalności, wyposażonego częstokroć w profesjonalny aparat zarządzająco-nadzorczy, nie powinno się jednak wymagać dochowania wyższego stopnia staranności w obszarze przestrzegania przepisów prawa wyznaczających reguły wykonywania określonej aktywności gospodarczej. Wracając do kwestii aspektów faktycznych prowadzonej działalności, wskazać można, iż nie chodzi tutaj także o ocenę dotychczasowej działalności z punktu widzenia osiągnięcia bądź nie - sukcesu ekonomicznego, a zatem odnotowania zysku lub straty finansowej. Ten wymiar działalności podlega bowiem analizie w ramach przesłanki „możliwości finansowe”. Wydaje się jednak, że to ocenie prawnych aspektów tegoż „zachowania” należy nadać sens szerszy i mieć tutaj na względzie nie tylko dotychczasową działalność z perspektywy postanowień ustawy Prawo energetyczne, ale i w świetle poszanowania obowiązującego porządku prawnego in genere. Zasady prowadzenia działalności przez podmioty podlegające odpowiedzialności karnoadministracyjnej w myśl postanowień art. 56 p.e. określone są bowiem również przepisami innych aktów normatywnych, w szczególności rangi ustawowej, dotyczących materii uczciwej konkurencji, ochrony konsumentów, ochrony środowiska, itd. Na wymiar sankcji administracyjnej wpływać powinien bowiem dotychczasowy stosunek karanego podmiotu do przestrzegania przepisów prawa w ogóle, a nie tylko działalność w ramach której stwierdzono przypadek swoistej „zwykłej recydywy karnoadministracyjnej”, gdy dopuścił się on już uprzednio naruszenia prawa stanowiącego delikt energetyczny.

Ocena przestrzegania prawa $\mathrm{w}$ toku dotychczasowej działalności podmiotu, wobec którego prowadzone jest postępowanie w sprawie nałożenia kary pieniężnej, uwzględniać powinna z pewnością wyłącznie prawomocne rozstrzygnięcia administracyjne stwierdzające naruszenie przepisów prawa. $\mathrm{Z}$ uwagi zaś na brak regulacji dotyczących zatarcia ukarania sankcją administracyjną, chociażby w dziale IVa k.p.a pt. „Administracyjne kary pieniężne”, na wzór zatarcia skazania karą kryminalną - znanego ustawodawstwu karnemu, per analogiam uznać można byłoby, że skoro w myśl postanowień art. $189 \mathrm{~g} \S 1$ k.p.a. „Administracyjna kara pieniężna nie może zostać nałożona, jeżeli upłynęło pięć lat od dnia naruszenia

${ }^{34}$ M. Czarnecka, T. OgŁóDek, Prawo energetyczne. Komentarz, Legalis 2012/el., komentarz do art. 56, teza 18. 
prawa albo wystąpienia skutków naruszenia prawa", a tym samym w opinii ustawodawcy jest to termin niwelujący negatywne skutki społeczne, które pociągnęło za sobą naruszenie przepisów prawa administracyjnego, to również uwzględnianie przy ocenie wymiaru kary pieniężnej zdarzeń zaistniałych wcześniej niż 5 lat nie byłoby celowe.

\section{INNE DYREKTYWY WYMIARU KARY}

Po przedstawieniu dyrektyw wymiaru kary, do których uwzględniania zobowiązany jest Prezes URE z mocy ustawy Prawo energetyczne, zastanowić wypada się w tym miejscu również nad kwestią charakteru katalogu przesłanek określonych w art. 56 ust. 6 p.e., w szczególności zaś, czy jest to zamknięty wykaz okoliczności, które powinien uwzględnić Prezes URE w toku ustalania wysokości przedmiotowej sankcji, czy też są to dyrektywy obligatoryjne, ale wykaz ich nie jest zamknięty. Na wstępie rozważań poświęconych tej kwestii trzeba przypomnieć stanowisko wyrażone przez Sąd Najwyższy ${ }^{35}$, który odnosząc się do dyrektyw wymiaru administracyjnej kary pieniężnej, o której mowa w art. 111 ustawy z dnia 16 lutego 2007 r. o ochronie konkurencji i konsumentów ${ }^{36}$ i będąc zdania, że kary te „nie mają charakteru quasi-karnego, a zatem ich nałożenie nie wymaga dowiedzenia winy podmiotu obarczanego karą”, dodaje, że przywołany powyżej przepis ,wskazując normatywne podstawy ustalania wysokości kar pieniężnych, wyznacza pewne podstawowe ramy dla swobodnego uznania" Prezesa Urzędu Ochrony Konkurencji i Konsumentów [dalej: Prezes UOKiK], natomiast sam katalog przesłanek, którymi kierować powinien się tenże organ przy korzystaniu z uznaniowej kompetencji, jest dość ograniczony, ale równocześnie otwarty i może być doprecyzowywany tak w praktyce Prezesa UOKiK, jak i w orzecznictwie sądowym. Czy zatem i na gruncie Prawa energetycznego uznać należałoby, że wykaz dyrektyw wymiaru kary pieniężnej jest otwarty i Prezes URE może uzupełnić je w ramach swoistej swobody decyzyjnej? Wydaje się, że nie, jeśli chodzi o dowolne kategorie przesłanek. W przepisie art. 189d § 1 k.p.a. wskazano co prawda pewien katalog dyrektyw wymiaru kary pieniężnej, które zobligowane są stosować organy władzy publicznej umocowane do nakładania tego rodzaju sankcji. Należą do nich: waga i okoliczności naruszenia prawa, w szczególności potrzeba ochrony życia lub zdrowia, ochrony mienia w znacznych rozmiarach lub ochrony ważnego interesu

${ }^{35}$ Wyrok Sądu Najwyższego z dnia 3 października 2013 r., sygn. akt III SK 51/12, Legalis nr 877725.

${ }^{36}$ Dz.U. z 2019 r., poz. 369 z późn. zm. 
publicznego lub wyjątkowo ważnego interesu strony oraz czas trwania tego naruszenia; częstotliwość niedopełniania w przeszłości obowiązku albo naruszania zakazu tego samego rodzaju co niedopełnienie obowiązku albo naruszenie zakazu, w następstwie którego ma być nałożona kara; uprzednie ukaranie za to samo zachowanie za przestępstwo, przestępstwo skarbowe, wykroczenie lub wykroczenie skarbowe; stopień przyczynienia się strony, na którą jest nakładana administracyjna kara pieniężna, do powstania naruszenia prawa; działania podjęte przez stronę dobrowolnie w celu uniknięcia skutków naruszenia prawa; wysokość korzyści, którą strona osiągnęła, lub straty, której uniknęła; w przypadku osoby fizycznej warunki osobiste strony, na którą administracyjna kara pieniężna jest nakładana. Niemniej przepis art. 189a $\S 2$ k.p.a. wskazuje wprost, że w razie uregulowania w przepisach odrębnych m.in. przesłanek wymiaru administracyjnej kary pieniężnej, w tym zakresie nie stosuje się przepisów działu IVa k.p.a pt. „Administracyjne kary pieniężne" 37 , jakkolwiek można mieć pewne wątpliwości, jak ta regulacja ma się do ostatniej, spośród kodeksowych, przesłanki wymiaru kary dedykowanej wyłącznie osobie fizycznej podlegającej karze pieniężnej, a nakazującej uwzględnienie jej warunków osobistych, skoro Prawo energetyczne nie zna dyrektywy przypisanej wyłącznie tej kategorii „sprawców” deliktów administracyjnych tam wskazanych.

Przy tym wszystkim pamiętać należy jednak, że Prezes URE, tak jak i każdy inny organ władzy publicznej, zobowiązany jest - stosując Prawo energetyczne przestrzegać zasad wyznaczonych innymi przepisami powszechnie obowiązującego prawa, zwłaszcza rangi konstytucyjnej. Dlatego też oczywiste jest, że określając wymiar kary pieniężnej, o której mowa w art. 56 ust. 1 p.e., uwzględnić musi w szczególności zasadę proporcjonalności wynikającą z art. 31 ust. 3 Konstytucji Rzeczypospolitej Polskiej z dnia 2 kwietnia $1997 \mathrm{r}^{38}$, a wyprowadzaną również z przepisu art. 2 Konstytucji RP, ustanawiającego zasadę demokratycznego państwa prawnego. Jest ona podstawową regułą wyznaczającą granice ingerencji organów władzy publicznej w konstytucyjne wolności i prawa człowieka i obywatela, a równocześnie nakazującą miarkowanie tejże ingerencji. W opinii Trybunału Konstytucyjnego ograniczenia praw konstytucyjnych nie naruszają zasady proporcjonalności wówczas, gdy: umożliwiają efektywną realizację założonych celów, nie jest możliwe zrealizowanie tychże celów przy pomocy środków mniej restryktywnych, a ich efekty są proporcjonalne względem ciężarów nakładanych nimi na jednostkę ${ }^{39}$. Określając wymiar kary pieniężnej adekwatny do okolicz-

${ }^{37}$ P. ZDYB, Wymierzanie administracyjnych kar pieniężnych przez Prezesa Urzędu Regulacji Energetyki w świetle nowelizacji kodeksu postepowania administracyjnego z dnia 7 kwietnia 2017 r., „Internetowy Kwartalnik Antymonopolowy i Regulacyjny” 6 (2017), s. 65.

${ }^{38}$ Dz. U. Nr 78, poz. 483 z późn. zm. [dalej cyt.: Konstytucja RP].

${ }^{39}$ Wyrok Trybunału Konstytucyjnego z dnia 20 lutego 2008 r., sygn. akt K 30/07, LEX nr 346025. 
ności konkretnego deliktu administracyjnego, niezależnie od dokonania oceny szkodliwości czynu (naruszenia), towarzyszącego mu stopnia zawinienia, a także możliwości finansowych i dotychczasowego zachowania (działalności) podmiotu podlegającego karze, Prezes URE mieć musi na względzie trzy kwestie. Po pierwsze, czy nałożenie kary pieniężnej jest nieodzowne, a zatem czy stopień szkodliwości naruszenia wyklucza możliwość odstąpienia od jej nałożenia w trybie art. 56 ust. 6a p.e. Po drugie, czy wysokość nałożonej sankcji zapewni realizację funkcji pełnionych przez karę pieniężną jako instrument oddziaływania na uczestników rynku energetycznego, przede wszystkim zaś funkcji prewencyjnej i represyjnej. Po trzecie, czy poziom uszczerbku finansowego towarzyszącej nałożeniu przedmiotowej sankcji jest proporcjonalny do efektów uzyskanych poprzez wyrządzenie tejże dolegliwości podmiotowi ukaranemu.

\section{UWAGI KOŃCOWE}

Odpowiedzialność karnoadministracyjna, jakkolwiek nie niesie za sobą takiego ciężaru nagany moralnej, jak w przypadku odpowiedzialności karnej, to w przypadku zagrożenia deliktu administracyjnego karą pieniężną może być równie, jeśli nie bardziej dolegliwa, a to z racji na rozmiary finansowe tej kategorii sankcji. Co prawda w orzecznictwie wskazuje się na konieczność zapewnienia stronie postępowania karnoadministracyjnego możliwości sądowej weryfikacji prawidłowości orzeczenia odpowiadającej wymogom towarzyszącym oskarżonemu w procesie karnym $^{40}$, ale sam wymiar nakładanej kary pieniężnej pozostawiony jest organowi administracji publicznej działającemu w tym zakresie zwykle w ramach uznania administracyjnego. Niezbędne jest zatem obwarowanie przyznanej mu swobody decyzyjnej takimi warunkami, które prowadziłyby do nakładania kary adekwatnej pod względem poziomu wyrządzanego nią uszczerbku ekonomicznego. Rolę taką pełnią zatem w pierwszym rzędzie ustawowo określone granice kary pieniężnej, a ponadto określone również ustawowo przesłanki jej wymiaru, które służyć mają przede wszystkim indywidualizacji odpłaty aparatu państwowego za naruszenie porządku prawnego wynikającego z przepisów prawa administracyjnego i dostosowaniu wysokości sankcji do konkretnego deliktu administracyjnego. W przypadku regulacji dotyczących odpowiedzialności karnoadministracyjnej znanej Prawu energetycznemu, zgodnie z postanowieniami art. 56 ust. 6 p.e., Prezes URE kierować ma się takimi wytycznymi wspomagającymi proces określania wysokości kary

${ }^{40}$ Zob. np. Wyrok Sądu Najwyższego z dnia 14 kwietnia 2010 r., sygn. akt III SK 1/10, Legalis nr 385429 . 
pieniężnej, jak: stopień szkodliwości czynu, stopień zawinienia, dotychczasowe zachowanie podmiotu oraz jego możliwości finansowe. Wspomnieć przy tym trzeba, że przesłankami tego rodzaju posłużył się ustawodawca również na gruncie innych aktów normatywnych rangi ustawowej określających zasady odpowiedzialności karnoadministracyjnej. Niemniej zwrócić należy uwagę na problemy towarzyszące ich zdefiniowaniu, w szczególności konieczność korzystania z dorobku nauki prawa karnego i judykatury, tak jak ma to miejsce chociażby w przypadku kwestii oceny szkodliwości czynu. Wskazać także trzeba na potrzebę rozważenia dookreślenia samej terminologii wykorzystanej tutaj przez ustawodawcę, która nie jest w pełni adekwatna do specyfiki niektórych kategorii podmiotów podlegającej odpowiedzialności karnoadministracyjnej w Prawie energetycznym, np. dotychczasowa działalność podmiotu w miejsce dotychczasowego zachowania podmiotu. Pochylić należy się wreszcie na koniec i nad kryterium stopnia zawinienia, a to z uwagi na obiektywny charakter odpowiedzialności karnoadministracyjnej, jak również trudności towarzyszące jego ocenie, zwłaszcza w przypadku, gdy podmiotem odpowiedzialności staje się podmiot o charakterze korporacyjnym.

\section{BIBLIOGRAFIA}

\section{ŹRÓDŁA PRAWA}

Konstytucja Rzeczypospolitej Polskiej z dnia 2 kwietnia 1997 r., Dz. U. Nr 78, poz. 483 z późn. zm. Ustawa z dnia 23 kwietnia 1964 r. Kodeks cywilny, Dz. U. z 2019 r., poz. 1145 z późn. zm.

Ustawa z dnia 10 kwietnia 1997 r. Prawo energetyczne, Dz.U. z 2019 r., poz. 755 z późn. zm.

Ustawa z dnia 6 czerwca 1997 r. Kodeks karny, Dz. U. z 2019 r., poz. 1950 z późn. zm.

Ustawa z dnia 28 października 2002 r. o odpowiedzialności podmiotów zbiorowych za czyny zabronione pod groźbą kary, Dz. U. z 2019 r., poz. 628 z późn. zm.

Ustawa z dnia 12 grudnia 2003 r. o ogólnym bezpieczeństwie produktów, Dz.U. z 2016 r., poz. 2047 z późn. zm.

Ustawa z dnia 16 lipca 2004 r. Prawo telekomunikacyjne, Dz. U. z 2019 r., poz. 2460 z późn. zm.

Ustawa z dnia 16 lutego 2007 r. o ochronie konkurencji i konsumentów, Dz. U. z 2019 r., poz. 369 z późn. zm.

Ustawa z dnia 27 sierpnia 2009 r. o finansach publicznych, Dz. U. z 2019 r., poz. 869 z późn. zm. Ustawa z dnia 23 listopada 2012 r. Prawo pocztowe, Dz. U. z 2018 r., poz. 2188 z późn. zm.

\section{ORZECZNICTWO}

Wyrok Trybunału Konstytucyjnego z dnia 20 lutego 2008 r., sygn. akt K 30/07, LEX nr 346025. Wyrok Sądu Najwyższego z dnia 10 lutego 2009 r., sygn. akt WA 1/09, Legalis nr 238904.

Wyrok Sądu Najwyższego z dnia 14 kwietnia 2010 r., sygn. akt III SK 1/10, Legalis nr 385429. Wyrok Sądu Najwyższego z dnia 3 października 2013 r., sygn. akt III SK 51/12, Legalis nr 877725. Wyrok Sądu Najwyższego z dnia 15 grudnia 2017 r., sygn. akt SNO 51/17, Legalis nr 1713888. 
Postanowienie Sądu Najwyższego z dnia 5 maja 2009 r., sygn. akt IV KK 427/08, Legalis nr 158190. Postanowienie Sądu Najwyższego z dnia 5 grudnia 2013 r., sygn. akt III SK 24/13, Legalis nr 753722. Postanowienie Sądu Najwyższego z dnia 13 maja 2015 r., sygn. akt II KK 60/15, Legalis nr 1285380. Wyrok Sądu Apelacyjnego w Katowicach z dnia 13 stycznia 2005 r., sygn. akt II AKa 455/04, Legalis nr 71610.

Wyrok Sądu Apelacyjnego w Łodzi z dnia 18 marca 2014 r., sygn. akt II AKa 28/14, Legalis nr 831415. Wyrok Sądu Apelacyjnego w Warszawie z dnia 16 grudnia 2016 r., sygn. akt VI ACa 1365/15, Legalis nr 1576321.

Wyrok Sądu Apelacyjnego w Warszawie z dnia 8 lutego 2017 r., sygn. akt VI ACa 1922/15, Legalis nr 1636709.

Wyrok Sądu Okręgowego w Warszawie z dnia 30 czerwca 2015 r., sygn. akt XVII AmE 49/14, Legalis nr 1325972.

Wyrok Sądu Ochrony Konkurencji i Konsumentów z dnia 18 lipca 2013 r., sygn. akt XVII AmE 119/11, Legalis nr 1326114.

Wyrok Sądu Ochrony Konkurencji i Konsumentów z dnia 9 maja 2016 r., sygn. akt XVII AmE 130/14, Legalis nr 1751948.

Wyrok Sądu Ochrony Konkurencji i Konsumentów z dnia 12 maja 2017 r., sygn. akt XVII AmE 118/15, Legalis nr 1751936.

Wyrok Sądu Ochrony Konkurencji i Konsumentów z dnia 23 listopada 2018 r., sygn. akt XVII AmE 106/16, Legalis nr 1887448.

Wyrok Sądu Ochrony Konkurencji i Konsumentów z dnia 27 listopada 2018 r., sygn. akt XVII AmE 297/18, Legalis nr 2127543.

Wyrok Sądu Ochrony Konkurencji i Konsumentów z dnia 13 sierpnia 2019 r, sygn. akt XVII AmE 236/17, Legalis nr 2257705.

Wyrok Sądu Ochrony Konkurencji i Konsumentów z dnia 23 października 2019 r., sygn. akt XVII AmE 360/18, Legalis nr 2257355.

\section{LITERATURA}

Czarnecka Marzena, Oglódek Tomasz: Prawo energetyczne. Komentarz, Legalis 2012/el.

Kodeks cywilny. Komentarz, t. II, red. M. Gutowski, Legalis 2019/el.

Kodeks karny. Komentarz, red. A. Grześkowiak, K. Wiak, Legalis 2019/el.

Kodeks karny. Komentarz, red. R. Stefański, Legalis 2019/el.

Kodeks postępowania administracyjnego. Komentarz, red. R. Hauser, M. Wierzbowski, Legalis 2018/el.

KRóL-BogomilsKa Małgorzata: Kary pieniężne w prawie antymonopolowym, Warszawa: Wydawnictwo KiK 2001.

KRUK Emil: Sankcja administracyjna, Lublin: Wydawnictwo UMCS 2013.

Piątek Stanisław: Prawo telekomunikacyjne. Komentarz, Warszawa: Wydawnictwo C.H. Beck 2019.

Prawo energetyczne. Komentarz, red. M. Kuliński Legalis 2017/el.

PrzYBysz Piotr: Funkcje sankcji administracyjnych, [w:] Sankcje administracyjne, red. M. Stahl, R. Lewicka, M. Lewicki, Warszawa: Wolters Kluwer Polska Sp. z o.o. 2011, s. 161-171.

URBAŃSKA-ARENDT Marta: Wpływ EKPC na uwzględnienie „winy” jako przesłanki dopuszczalności nakładania kar pieniężnych w orzecznictwie dotyczącym deliktów prawa antymonopolowego i energetycznego, Internetowy Kwartalnik Antymonopolowy i Regulacyjny 6 (2017), s. 41-53.

ZDYв Przemysław: Wymierzanie administracyjnych kar pieniężnych przez Prezesa Urzędu Regulacji Energetyki w świetle nowelizacji kodeksu postępowania administracyjnego z dnia 7 kwietnia 2017 r., Internetowy Kwartalnik Antymonopolowy i Regulacyjny 6 (2017), s. 54-67. 


\title{
DYREKTYWY WYMIARU KARY PIENIĘŻNEJ W PRAWIE ENERGETYCZNYM
}

\author{
Streszczenie
}

Prawo energetyczne z 1997 r. przyznaje Prezesowi URE uprawnienie do nakładania kary pieniężnej za naruszenia godzące $\mathrm{w}$ zasady prowadzenia działalności w dziedzinie energetyki. Wysokość tej sankcji ustalona została w przypadków większości deliktów administracyjnych przedziałami kwotowymi lub relacją do przychodu karanego podmiotu. Określając wymiar wspomnianej sankcji Prezes URE zobowiązany jest uwzględnić: stopień szkodliwości czynu, stopień zawinienia, dotychczasowe zachowanie podmiotu oraz jego możliwości finansowe. Dyrektywy te mają zapewnić indywidualizację sankcji nakładanej za naruszenie zaistniałe w konkretnych okolicznościach. Zarówno przy ocenie stopnia szkodliwości czynu, jak i stopnia zawinienia, niezbędne okazać się może skorzystanie z dorobku doktryny prawa karnego. W przypadku dotychczasowej działalności karanego podmiotu istotna jest weryfikacja przestrzegania przez niego obowiązującego porządku prawnego. Ocena możliwości finansowych zapobiegać ma natomiast nakładaniu kar pieniężnych, które byłyby nadmierne dotkliwe względem naruszenia przepisów prawa. Analiza treści przesłanek wymiaru kary pieniężnej w Prawie energetycznym prowadzi do wniosku, że ich wprowadzenie przez ustawodawcę jest zasadne, jakkolwiek w pierwszym rzędzie Prezes URE powinien kierować się w trakcie stosowania sankcji administracyjnych konstytucyjną zasadą proporcjonalności. Należy również rozważyć modyfikację terminologii celem dostosowania brzmienia dyrektyw wymiaru kary pieniężnej do wszystkich kategorii podmiotów jej podlegających.

Słowa kluczowe: prawo energetyczne; kara pieniężna; dyrektywy wymiaru kary

\section{THE DIRECTIVES OF PENALTY DIMENSION IN ENERGY LAW}

\section{Sum mary}

The Energy Law of 1997 gives the President of Energy Regulatory Office (President of ERO) the power to impose a financial penalty for violating the principles of conducting business in the field of energy. The amount of the sanction was set for most administrative offences by amount ranges or by relation to the income of the penalized entity. When determining the dimension of the said sanction, the President of ERO is obliged to take into account: the degree of harmfulness of the act, the degree of fault, the entity's previous behavior and its financial potential. These directives are intended to ensure the individualisation of the sanction imposed for an infringement in specific circumstances. Both in assessing the harmfulness of the act and the degree of culpability, it may be necessary to use the achievements of the doctrine of criminal law. In the case of the previous activity of a punished entity, it is important to verify compliance with the applicable legal order. The assessment of financial potential is, however, to prevent the imposition of fines that would be excessively severe in relation to the breach of law. The analysis of the content of the conditions for the imposition of a punishment in energy law leads to the conclusion that their introduction by the legislator is justified, although in the first place the President of ERO should be guided in the application of administrative sanctions by the constitutional principle of proportionality. Modification of terminology should also be considered in order to adapt the wording of the financial penalty directives to all categories of entities which are subject to it.

Key words: energy law; financial punishment; penalty directives 